\title{
Analysis on Path for Management-oriented Transformation of Talent Training of Accounting Major in Higher Vocational College
}

\author{
Xia Lei \\ Chongqing Business Vocational College \\ Chongqing, China
}

\begin{abstract}
The rapid development of Internet technology has great impact on accounting industry. There is huge reduction in calculating financial accountant, so the transformation of accountants has become inevitable, and transforming to management accounting has become the only direction. Therefore, this paper analyzes the problems of current training objectives, curriculum system, teaching methods and teaching staff of talent training of accounting major in higher vocational college. On this basis, the paper puts forward the path of the transformation of the accounting specialty to the "management type", and analyzes the main factors which affect success of the transformation.
\end{abstract}

Keywords-management type; higher vocational college; accounting major; talent training; transformation

\section{INTRODUCTION}

No.27 The guidance of the Ministry of Finance on comprehensively promoting the construction of management accounting system in Finance and Accounting [2014] of 2014 points out that "Management accounting is an important branch of accounting...however, the development of management accounting in our country is lagging behind, so it is urgent to deepen accounting reform and strengthen management accounting." It's the first time to put forward that we should "base on the construction of management accounting talents," which kicked off the rapid development of China's management accounting. On June 22, 2016,the Ministry of Finance issued the Basic Guidelines on Management accounting, and on October 8, 2016, the ministry of finance issued the Outline of the 13th Five-year Plan for Accounting Reform and Development, further pointed out that we should "comprehensively strengthen the construction of management accounting system, guide and promote the effective application of management accounting." In December, 2016, the Ministry of Finance released 22 management accounting application guidelines, such as Management Accounting Application Guidance - No. 100 - Strategic Management, and solicited opinions from the public. We can feel the urgent idea of developing

Fund project: This paper is one of the periodic research results of Management-oriented Research and Practice of Innovative Talent Training and Orientation of Accounting Major in Higher Vocational College, the key project of Chongqing City's Higher Education Teaching Reform and Research (Project No. 162088) management accounting in the top level design of the country from this series of documents. The era of "management accounting" has already come, and financial personnel must achieve the transformation rapidly from traditional "accounting type" to "management type", otherwise, they cannot keep up with the development of the times, and face the danger of being engulfed by the tide of reform. The education of accounting major in higher vocational training future accounting talent must conform to the development of the times and reform rapidly, and especially for business-class schools, finance and economics is the first major of business class in higher vocational colleges with full annual enrollment. There are two main reasons for it. On the one hand, the number of accounting major grows increasingly. On the other hand, the demand for accounting personnel of accounting type has decreased, while the demand for management-typed accounting talents has increased. The author ponders on the future of accounting major and this paper will make a discussion for it.

\section{PROBLEMS EXISTING IN THE TRAINING OF ACCOUNTING MAJOR IN HighER VOCATIONAL COLLEGES}

\section{A. The Problems Existing in the Training Objective of Accounting Major in Higher Vocational Colleges}

Talent training objective is the important part and baton of talent training, which solves the problem of cultivating what kind of person in the process of talent cultivation. Although higher vocational colleges have their own ideas for training objective of accounting major, the difference is extremely subtle. Basically, they take "the ability of making account" as the core of the training objective, and accounting ability or accounting processing capacity is the core skills of the accounting major. Internet + , big data, financial robot, financial sharing and so on bring far-reaching impact on the financial work. Simple, standardized and high repetition of the work done by accounting personnel of accounting type will be replaced by the financial robot in the near future, and what can financial staff do in the intelligent era? Of course, only the work that cannot be replaced by the intelligent machine is the direction of the future financial development, which includes advance prediction and decision-making, dynamic control in the matter, afterwards analysis, 
participation in the whole process of operation and management of the enterprise. According to the statistics, $80 \%$ of America's financial personnel are management accountants. It is predicted $70 \%$ of the financial personnel in China will face the transformation. Therefore, the training objective of accounting major in higher vocational colleges must be re-oriented, that is, from "accounting typed financial accountant" to "management-typed accountant".

\section{B. Problems Existing in the Curriculum System of Accounting Major in Higher Vocational College}

The curriculum system of higher vocational colleges is generally divided into public compulsory course, professional required course, specialized elective course and specialized concentrated practice course. Public compulsory courses are generally formulated by the academic office of the College, while professional required course, professional elective course and professional concentration of practical course are formulated by the professional leaders in the basis of professional research, each year according to the needs of appropriate amendments, making appropriate revisions as needed each year. But the problem is, firstly, most of the accounting majors in higher vocational colleges are relatively mature and the curriculum system is relatively fixed, and the annual revision is also minor, not daring to make drastic changes. Secondly, the curriculum system of higher vocational education is in accordance with the undergraduate science system, or deepens in the secondary vocational curriculum system. At present, higher vocational education doesn't have a relatively independent and mature curriculum system. In addition, education in the western region is relatively backward, not catching some advanced education concepts and methods in time, which makes the curriculum system lags behind developed areas. Because of the slow acceptance for new knowledge and new things and conservation, the courses still keep the same. Accounting courses occupy more than $80 \%$ of the professional teaching of the original curriculum system, which lacks professional culture and vocational spirit education courses, Internet + courses, general courses in economic management. As a result, the students we cultivate make study deviate from practical work, and don't learn what they can't.

\section{Problems Existing in the Teaching Method of Accounting Major in Higher Vocational College}

Teaching methods of accounting major is seriously backward and most schools still adopt the traditional teaching method with all teaching locations in the classroom. For simple teaching, listening, the teacher is parched and students feel sleepy when experiencing a lesson, which we can predict the teaching effect. What are more worrying are the restrictions on school's hardware conditions with all practice teaching in the classroom. Students make presentation first, and then the teacher explains it when finding the problem. However, teacher fails to find each student's problem in traditional teaching method, and students do not know whether they are correct or not. As a result, students can't grasp the skills of practice correctly. At present, the application of information technology is very limited in the teaching of accounting major of higher vocational education.

\section{Problems Existing in the Teaching Staff of Accounting Major in Higher Vocational College}

First of all, the teachers of higher vocational colleges are mainly composed by excellent undergraduate, postgraduate and doctoral students, who generally start teaching simply with short-time pre-job training immediately after their graduation. Undergraduates and graduate students mainly acquire theoretical knowledge without practical experience, making teaching dominated by empty theory. Secondly, "double qualified" teachers in higher vocational education are not veritable. "Double qualified" teacher is the basic requirement for professional teacher, but a lot of schools interpret it as teacher certification and professional and technical title certificate, and those who possess double certificates are double qualified teachers. Moreover, the teaching workload of accounting teachers of higher vocational college is very heavy that teachers are tired to complete teaching work, without reflection on education and teaching, which cannot further improve their professional skills, and professional development is seriously restricted. In addition, there are few opportunities for teachers of higher vocational colleges to improve their business and go out to study. The root makes transformation difficult is because of accounting teachers' unawareness of their selftransformation, the lack of management accounting knowledge system, and the lack of source power in transformation.

\section{PATH OF MANAGEMENT-ORIENTED TRANSFORMATION FOR ACCOUNTING MAJOR IN HIGHER VOCATIONAL COLLEGE}

\section{A. Re-orientation of Training Objective of Accounting Major in Higher Vocational Colleges}

First of all, our orientation of training objective should be in accordance with the National Education Strategy, the goal of personnel training of higher vocational education put forward by the Ministry of Education is "high-quality technical skilled talent", the first requirement for personnel training of higher vocational college is "quality", which refers to the character, quality and morality of a person. The second one is "technical skills", of which the key word "skill" is "what people makes a living", such as "professional skills" Lastly, "talent" is defined by Baidu Encyclopedia as "someone possesses a certain degree of professional knowledge or expertise, does creative labor, and contributes to the society". Therefore, the orientation of "high quality technical skill talents" is someone with lofty moral character, strong professional ability and innovative thinking. The primary goal of education is cultivation of professional ethics and professional spirit, while the moral education in our talent training is missing, and moral quality is the fundamental of education and teaching. Secondly, the cultivation of technical skills in higher vocational colleges is not only cultivating the production workers, but also the cultivation of the ability of reemployment and development 
of the first-time employment. Therefore, the author doesn't think it is right for the training concept of "theory is enough, practice is the most important". What is enough? How to measure it? Only understanding the operation but does not understand the principle will severely limit the higher vocational students' follow-up development ability. Furthermore, innovative entrepreneurship education should also be highlighted in talent training. But we do not mean that every student should engage in innovative entrepreneurship. What we train is students' innovative concept and thinking, students' hard-working spirit, perseverance and upright quality in the process of entrepreneurship. Therefore, our talent training goal is that quality; knowledge and skill develop in coordination and face the future.

\section{B. Reconstruction of the Curriculum System of Accounting Specialty in Higher Vocational Education}

The course of accounting major in higher vocational education must be reconstructed in real time combining with the new dynamic of the development of accounting industry, and the curriculum system based on financial accounting is adjusted to base on management accounting. Firstly, qualityoriented education courses and cultivating students' professional spirit, such as Accounting Culture, Accounting Professional Ethics and Business Culture, should be increased. Secondly, the general-knowledge course of economic management to broaden the view of knowledge, such as Fundamentals of Management, Marketing Fundamentals, Fundamentals of Economics and Finance and Banking, should be increased. Accounting courses, The Basis of Accounting, Financial Accounting, Cost Accounting, Common Industry Accounting can be merged into Enterprise Financial Accounting, increasing Management Accounting, Financial Budget, Risk Management, Internal Control System, and so on. Fourthly, the training of accounting skills should be turned to the cultivation of comprehensive management ability, such as ERP Sand Table, Financial Sharing Simulation Training, Supply Chain Management, etc. Fifthly, it is advisable to offer innovative entrepreneurship courses, hold innovative entrepreneurship competition, provide innovative entrepreneurship training venues and invite venture stars to give lectures.

\section{Diversification of Teaching Methods for Accounting Major in Higher Vocational Education}

As higher vocational educators, we know that higher vocational students are characterized by insufficient consciousness and self-confidence and strong dependence and behavioral inertia, but they are keen on colorful activities with flexible thinking and rich ideas. If changing the rigid and simple teaching methods, actually we can rejoice at finding that their growth is so rapid. We should apply the modern teaching methods to higher vocational education effectively, such as taking teaching as a whole, integrating theory and practice, overturning class, micro-class and MOOC. In addition, rich and colorful teaching means should also be applied to practical teaching, especially by means of informatization, such as establishing network training platform and realizing teacher-student interaction through the internet, accurately mastering specific training situations and differentiating teaching in accordance with the situation of each student, so as to truly achieve the purpose of simulation training.

\section{Construction of "Double-qualified" Teacher Team of Accounting Specialty in Higher Vocational Education}

Teachers are the key to education and teaching, and the implementation of the goal of talent training, the effective transformation of the curriculum structure and the application of modern teaching methods cannot be separated from teachers. And the quality of the faculty determines the success of the education, so the construction of the teacher team is the first priority for school's development. Except for teachers' professional ethics and the knowledge of teachers' specialized theories, "professionalism" is the characteristic of the professional teachers in higher vocational colleges, and the professional requires good understanding of the accounting work and the development of accounting profession, and it also requires teachers in higher vocational college must dock the industry. First of all, new teachers must experience practice in the enterprise's financial position for at least six months before formally entering the teaching position. Besides, each teacher must experience practice in the enterprise for more than 20 days. Moreover, encouraging and supporting teachers to do parttime job and take a temporary post in the enterprise, etc. Furthermore, teachers must go to the developed regions to learn and exchange advanced experience, thinking closely with the development of the times. What the accounting major of higher vocational education needs is the real double-qualified teacher.

\section{SUCCESSFUL FACTORS OF MANAGEMENT-ORIENTED TRANSFORMATION FOR ACCOUNTING MAJOR IN HIGHER VOCATIONAL COLLEGE}

\section{A. Strategic Thought of the Leadership of Higher Vocational Colleges}

The development of professional development is inseparable from the support of the school and the strategic development thought of the college leadership. On the one hand, we should consider the enrollment scale, which affects the economic source of the college, because enrollment is the source of income. On the other hand, we should consider the input of the school, including the construction of the campus and the faculty, the professional construction, scientific research and so on. College leadership has to consider the long-term development of the college in professional enrollment scale and how to allocate the limited economic resources. Accounting major of higher vocational college takes high enrollment in business class of higher vocational colleges; however, there is little investment in accounting major's teaching resources construction. If there is no resources investment in accounting major, such as informationalized training place and training platform, not strengthening the cooperation of college-enterprise and the cultivated talents cannot effectively meet the demand of the society. How to develop for a long term? Therefore, for 
making future development strategy, the leadership should not only consider the current interests, but also the future development trend. Accounting major scale of higher vocational college cannot be expanded, and it is fundamental to increase the investment in teaching resources, strengthen the cultivation of teachers and the education of students' quality based on maintaining the current scale.

\section{B. Change of Ideological Concept and Improvement of Professional Skills of Accounting Teachers in Higher Vocational College}

Information technology changes with each passing day, and society changes greatly every day. Wake up! We can't remain trapped in our limited view and narrow-minded conservation. The era of intelligence is coming, the era of relying on a piece of chalk and a textbook gone. Accounting teachers of higher vocational college should change the old ideas, keep up with the pace of the Internet + , learn the production technology of micro-course and MOOC, acquire the knowledge of management accounting, exercise practice skills in enterprise's financial position deeply, making yourselves successful "management-typed" accounting teachers.

\section{Cultivation of Vocational Spirit and Comprehensive Ability of Higher Vocational Students}

Students are the main body of education and teaching. Teachers and students, and teaching-learning promote teaching. According to many years of teaching experience, it is found that higher vocational students lack the positive, hardworking and persistent spirit, and they do not want to take actions and give up easily while facing difficulties. In a word, they have bad consciousness. Consciousness determines behavior, attitude and altitude, so we should cultivate students from the aspects of conscious and at spiritual level. Educating people is the root for education. In addition, we should guide students to realize the urgency and necessity of accounting transformation through various channels, making them realize that the future belongs to versatile talents, and strengthen the cultivation of their comprehensive abilities.

\section{CONCLUSION}

Transformation of accounting talent cultivation of higher vocational college is a major and systematic engineering. It is not only the matters of a person, but it needs comprehensive coordination and top design of leadership, each professional teacher's thought transformation and active participation, and students' main role in teaching. The intelligent era has come, and we can't escape but face the challenge. Only by rapidly achieving the transformation from accounting type to management type can we win a place in the future financial industry.

\section{REFERENCES}

[1] Ma Yuanxing. The Breakthrough and Reconstruction of Teaching Standard of Accounting Major in Higher Vocational College [J].Vocational and Technical Education, 2016 (07): 34-37.
[2] Qiao Xueqin, Analysis of mode transformation of talent cultivation of Accounting Major in Higher Vocational College Base on Internet+ [J].Education Forum, 2016 (12) :243-244.

[3] Wang Jun, Tan Xianqiu, Qi Ganlu. An analysis of the training of Accounting Talents in Higher Vocational Colleges under the Era of "Internet +" [J].Journal of Anhui Electrical Engineering Professional Technique College, 2016 (12): 90-93.

[4] Dai Bohua. Adapting to the New Normal Integration and Promoting the Development of Accounting Reform and Development under the "Internet +" [J].Traffic Accounting, 2015 (8): 5-6.

[5] Shi Yonghong. Research on Training Mode and Teaching Method of Applied Management Accounting Talents in Higher Vocational Education [J]. Journal of Chuzhou Vocational and Technical College, 2016 (6): 55-57. 